\title{
Triatoma rubrovaria (Blanchard, 1843) (Hemiptera: Reduviidae) I: Isoenzymatic and Chromatic Patterns of Five Populations from the State of Rio Grande do Sul, Brazil
}

\section{Carlos Eduardo Almeida/*/+, Raquel S Pacheco**, François Noireau***/****, Jane Costa}

\author{
Núcleo de Informatização, Coleção Entomológica ***Laboratório Nacional e Internacional de Referência em Taxonomia de \\ Triatomíneos, Departamento de Entomologia **Laboratório de Sistemática Bioquímica, Departamento de Bioquímica e Biologia \\ Molecular, Instituto Oswaldo Cruz-Fiocruz, Av. Brasil 4365, 21045-900 Rio de Janeiro, RJ, Brasil *Núcleo Avançado de \\ Estudos de Artrópodes Peçonhentos e Vetores, Centro Universitário de Barra Mansa, Barra Mansa, RJ, Brasil \\ ***Institut de Recherche pour le Développement, UR016, Paris, France
}

Triatoma rubrovaria has become the most frequently captured triatomine species since the control of $\mathrm{T}$. infestans in the State of Rio Grande do Sul (RS), Brazil. In order to evaluate the genetic variability of this species, field collections were performed in four municipalities where it has been reported and distant from 75 to $322 \mathrm{~km}$. Specimens were analyzed by color pattern and isoenzymes. Nine enzymatic loci were interpreted from nine enzymatic systems. The Santiago population was isolated from the others with chromatic monomorphism and diagnostic alleles at Idh and Pgm loci. The study shows the existence of, at least, two distinct populations of T. rubrovaria in RS with different phenotypic and genetic pattern.

Key words: Triatoma rubrovaria - multilocus enzyme electrophoresis - chromatic studies - Rio Grande do Sul - Brazil

Triatoma rubrovaria (Blanchard, 1843) is widespread in Uruguay and parts of Northeastern Argentina. In Brazil, its presence has been confirmed only in the southern States of Paraná (PR) and Rio Grande do Sul (RS). This species is mainly found among rocks known as 'pedregales' and is considered generalist, feeding on a wide variety of vertebrate and invertebrate hosts (Salvatella et al. 1994, 1995). Salvatella et al. (1994) demonstrated that it does feed on humans and Silva and Silva (1993) showed its high competency as vector of Trypanosoma cruzi, the causative agent of Chagas disease.

Lent (1942) mentioned T. rubrovaria (cited as Eutriatoma rubrovaria) as an exclusively sylvatic species found in stone piles and peridomestic habitat in RS, but rarely encountered in human dwellings. However, subsequent authors have also mentioned the finding of this species in domiciliary habitats, but with no sign of successful colonization (Di Primo 1957, Lucena 1959, Correa 1968, Lent \& Wygodzinsky 1979). More recently, its potential for colonizing human dwellings was emphasized by Silveira and Rezende (1994).

Surveillance data gathered by the Brazilian National Health Foundation (Funasa) during the Chagas Disease Control Program (PCDCH) over the last 20 years show that the presence of $T$. rubrovaria in human dwellings has increased in Southern Brazil. However, there are no

Supported by Brazilian National Health Foundation, agreement term \#1159/98 and The State of Rio de Janeiro, Brazil, Research Foundation.

${ }^{+}$Corresponding author. Fax: +55-21-2573.4468. E-mail: almeidace@ioc.fiocruz.br

Received 24 January 2002

Accepted 15 May 2002 consistent clues of intradomiciliary colonization by $T$. rubrovaria. This species seems to present preadaptive characteristics for anthropic ecotopes, and should be kept under constant epidemiologic surveillance (Almeida et al. 2000).

Previous study on isoenzymatic and chromatic patterns of four T. brasiliensis populations from Northeastern Brazil has shown high genetic distances among them (Costa et al. 1997). Detailed study of these distinct populations will improve the understanding of the role of these "distinct melanic forms" in the transmission of Chagas disease (Costa et al. 1998). A chromatic polymorphism of pronotum has also been observed for T. rubrovaria populations from Uruguay and Southern Brazil (Lent 1942). The aim of this work was to investigate by multilocus enzyme electrophoresis and color pattern the genetic and phenotypic variability of T. rubrovaria populations issued from different localities in RS.

\section{MATERIALS AND METHODS}

Study areas - Specimens were collected in four municipalities of RS: Santana do Livramento (30 $53^{\circ} 27^{\prime \prime}$;

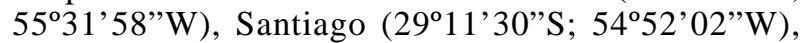
Canguçu (31'23'42”'S; 52 40'32”'W) and Encruzilhada

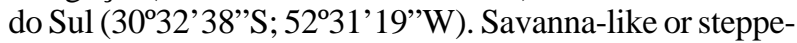
like subtropical mixed prairies are the predominant environmental characteristics (IBGE 1997). The distances (in $\mathrm{km}$ ) among the collection sites are given in Fig. 1. Chickens, dogs, pigs, cattle and sheeps are the most frequent domestic animals in the region when sylvatic animals are not common. The capture of insects was carried out in warm season, from October to March (1998-1999) in domiciliary, peridomiciliary and sylvatic-like ecotopes. Peridomiciliary habitat was considered $5-10 \mathrm{~m}$ from houses and was frequently delimited by stone walls, a type of construction made of overlapping rocks. They are used 


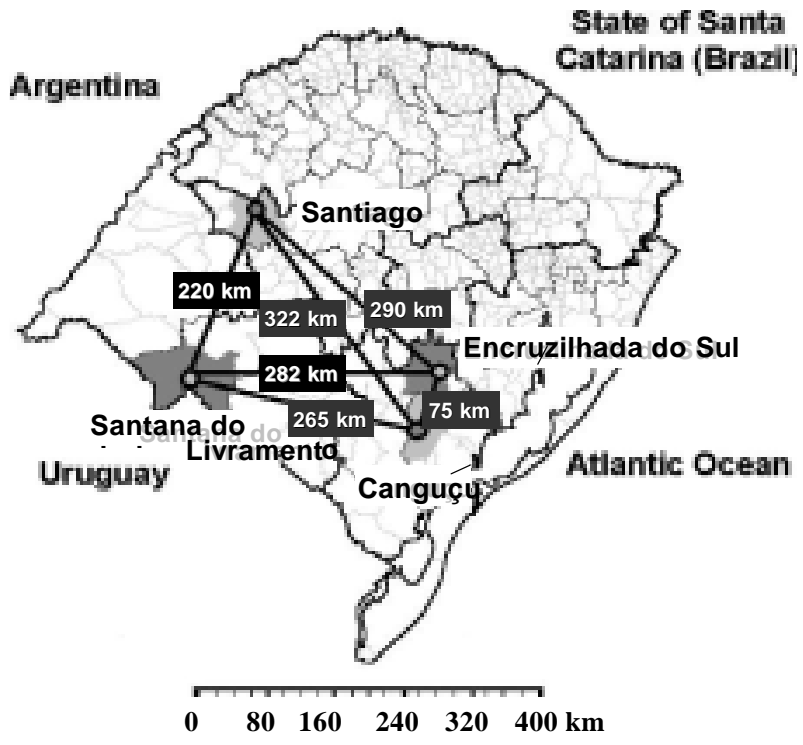

Fig. 1: map showing the geographic distance (in $\mathrm{km}$ ) between the collecting points of Triatoma rubrovaria in the State of Rio Grande do Sul, Brazil.

as shelter by small animals and arthropods. The sylvaticlike environment, characterized by grass pastures for cattle and sheep feeding and called as "ruderale", is located more than $10 \mathrm{~m}$ far from houses. In this environment, triatomines were found in overlapping rocks on the ground and in the dry stonewalls used as fences between pieces of land.

Processing of insects - Insects were placed in plastic bottles containing filter paper and transported to the laboratory. Identification of adults was performed according to Lent and Wygodzinsky (1979).

Isoenzyme electrophoresis - A total of 141 live adult specimens were used. The technique was performed on agarose gel as described for anophelines by Rosa-Freitas et al. (1992) and modified for triatomines by Costa et al. (1997). The analysis was performed in wild collected insects, except for Santana do Livramento population where F1 was used. The localities where T. rubrovaria specimens were collected, their coordinates, the ecotopes, number of founder individuals (for Santana do Livramento population only), and number of insects studied are given in Table I. Thirty one specimens of T. infestans were used as an outgroup. Those specimens were issued from a colony (20 males and 20 females founders) collected in the State of Bahia, Brazil, in October 1981. The insects were cut between the prothorax and mesothorax. Prothorax and head were ground in $200 \mu \mathrm{l}$ of lysis buffer $(500 \mathrm{mM}$ Tris HCl, $26 \mathrm{mM}$ EDTA, $10 \mathrm{mM}$ DTT and $10 \mathrm{mM}$ E-aminocaproic acid) and $4 \mu \mathrm{l}$ of each homogenate was loaded in each track for electrophoresis. Fifteen enzymatic systems were tested: 6PGD - 6-Phosphogluconate dehydrogenase (E.C. 1.1.1.43), ACON - Aconitase (E.C. 4.2.1.3), FUM Fumarase (E.C. 4.2.1.2), G-6-PDH - Glucose-6-phosphate dehydrogenase (EC 1.1.1.49), GPI - Glucose phosphate isomerase (EC 5.3.1.9), HK - Hexokinase (E.C. 2.7.1.1), HBDH - ß-hydroxybutyrate dehydrogenase (E.C. 1.1.1.30), IDH - Isocitrate dehydrogenase (E.C. 1.1.1.42), MDH Malate dehydrogenase (E.C. 1.1.1.37), ME - Malic enzyme (E.C. 1.1.1.40), MPI - Manose-6-phosphate isomerase (E.C. 5.3.1.8), PEP2 - Aminopeptidase (E.C. 3.4.11, leucine1-Lalanina substrate), PEP3 - Aminopeptidase (E.C. 3.4.11, leucina1-leucinal substrate), PEPD - Proline dipeptidase (E.C. 3.4.13.9) and PGM - Phosphoglucomutase (E.C. 2.7.5.1).

Statistical methods applied to isoenzyme analysis Genotype frequencies were obtained by direct interpretation of bands on the gels. Genetic variability was estimated by the rate of polymorphism $(\mathrm{P})$, the mean number of alleles per locus (A) and the expected mean heterozygosity He (Nei 1987). Departures from panmixia were looked for using the fixation index (F). For the latter calculation, only two possible alleles were taken into account: the most frequent one, and all other ones plotted together as a unique allele. The standard genetic distance (Ds) of Nei (1987) was used to compare gene frequency differences between the geographic populations, and converted into an unweighted pair group method arithmetical average (UPGMA) dendrogram.

Analysis of chromatic pattern - Field specimens were utilized for the observation of the chromatic variation. Pronotum of each specimen was examined by using a stereoscopic microscope and typed according to the morphotypes described by Lent (1942). The distinct color patterns were illustrated using a digital camera.

\section{RESULTS}

In Santana do Livramento, T. rubrovaria specimens were collected in two sites, Ponte and Brigada, $10 \mathrm{~km}$ distant from each other and located in ruderale environment. In Ponte, specimens were collected in natural ecotopes (overlapping rocks - 'Ln' population) and in Brigada in artificial ones (stone walls - 'La' population). In Canguçu, triatomines were found only in stonewalls in the peridomicile and designated as ' $\mathrm{C}$ ' population. In Santiago and Encruzilhada do Sul, the specimens were collected

TABLE I

Data of Triatoma rubrovaria populations studied

\begin{tabular}{|c|c|c|c|c|c|}
\hline Population & Municipality & Location & Ecotope & $\begin{array}{l}\text { Number of } \\
\text { colony founded }\end{array}$ & $\begin{array}{c}\text { Number of } \\
\text { specimens utilized }\end{array}$ \\
\hline ‘Ln’ & Santana do Livramento & $30^{\circ} 53^{\prime} 27^{\prime \prime} \mathrm{S} 55^{\circ} 31^{\prime} 58^{\prime \prime} \mathrm{W}$ & Ruderale, overlap stones & 58 & $31(\mathrm{~F} 1)$ \\
\hline 'La' & Santana do Livramento & 3053'27’'S 55०31'58”W & Ruderale, stone's walls & 41 & $31(\mathrm{~F} 1)$ \\
\hline ‘S’ & Santiago & 29०11'30”'S 5452'02”'W & Ruderale, overlap stones & - & 31 (collected in field) \\
\hline 'C' & Canguçu & $31^{\circ} 23^{\prime} 42^{\prime \prime} \mathrm{S} 52^{\circ} 40^{\prime} 32^{\prime \prime} \mathrm{W}$ & Peridomicile stone's walls & - & 31 (collected in field) \\
\hline 'E' & Encruzilhada do Sul & $30^{\circ} 32^{\prime} 38^{\prime \prime} \mathrm{S} 52^{\circ} 31^{\prime} 19^{\prime \prime} \mathrm{W}$ & Ruderale, overlap stones & - & 17 (collected in field) \\
\hline
\end{tabular}


only in natural ecotope located in ruderale environment (populations ' $S$ ' and 'E', respectively) (Table I).

For the isoenzymatic analysis, nine out of the 15 systems tested gave readable results for the four populations of $T$. rubrovaria. The enzymes ACON, G-6-PDH, HK, HBDH, PEP2 and PEPD showed no activity or weak bands and were discarded from the analysis. Thus, the nine interpreted enzymes were 6PGD, FUM, GPI, IDH, MDH, ME, MPI, PEP3 and PGM. Among the nine analyzed loci, intra-populational polymorphism was only found for Pgm and $M p i$ loci. The Pgm locus was polymorphic only for the ' $S$ ' population, showing three alleles (Pgm-2, Pgm-3 and Pgm-4) under six possible combinations for homozygotes and heterozygotes. In this same locus, other $T$. rubrovaria populations were monomorphic with the Pgm-2 allele. Mpi locus was polymorphic for ' $\mathrm{Ln}$ ', 'C' and 'E' populations. For $I d h$, the 'S' population presented a monomorphic diagnostic allele (Idh-1) while the other T. rubrovaria populations presented the Idh-2 allele (Table II).

Within T. rubrovaria samples from each locality, departure from Hardy-Weinberg equilibrium was tested by the fixation index. Observed genotype frequencies for all alleles were consistent with random mating expectations (Table III). The greatest mean number of alleles per locus (A) and expected mean heterozygosity (He) were observed in 'S' population. Except for 'La' population monomorphic in all loci, other populations showed the same rate of polymorphism (Table II).

\section{TABLE II}

Allelic frequency at nine enzymatic loci in five Triatoma rubrovaria populations collected in different municipalities and ecotopes

\begin{tabular}{lccccccc}
\hline & & T. infestans & \multicolumn{5}{c}{$T$. rubrovaria } \\
\cline { 3 - 7 } Locus & Allele & (outgroup) & 'Ln' & 'La' & 'S' & 'C' & 'E' \\
\hline Pgm & 1 & 1.00 & 0.00 & 0.00 & 0.00 & 0.00 & 0.00 \\
& 2 & 0.00 & 1.00 & 1.00 & 0.30 & 1.00 & 1.00 \\
& 3 & 0.00 & 0.00 & 0.00 & 0.26 & 0.00 & 0.00 \\
& 4 & 0.00 & 0.00 & 0.00 & 0.44 & 0.00 & 0.00 \\
Idh & 1 & 0.00 & 0.00 & 0.00 & 1.00 & 0.00 & 0.00 \\
& 2 & 0.00 & 1.00 & 1.00 & 0.00 & 1.00 & 1.00 \\
& 3 & 1.00 & 0.00 & 0.00 & 0.00 & 0.00 & 0.00 \\
Me & 1 & 1.00 & 0.00 & 0.00 & 0.00 & 0.00 & 0.00 \\
& 2 & 0.00 & 1.00 & 1.00 & 1.00 & 1.00 & 1.00 \\
Mpi & 1 & 1.00 & 0.85 & 1.00 & 1.00 & 0.82 & 0.88 \\
& 2 & 0.00 & 0.15 & 0.00 & 0.00 & 0.18 & 0.12 \\
Mdh & 1 & 0.00 & 1.00 & 1.00 & 1.00 & 1.00 & 1.00 \\
& 2 & 1.00 & 0.00 & 0.00 & 0.00 & 0.00 & 0.00 \\
Pep3 & 1 & 1.00 & 0.00 & 0.00 & 0.00 & 0.00 & 0.00 \\
& 2 & 0.00 & 1.00 & 1.00 & 1.00 & 1.00 & 1.00 \\
Fum & 1 & 1.00 & 1.00 & 1.00 & 1.00 & 1.00 & 1.00 \\
6Pgd & 1 & 1.00 & 0.00 & 0.00 & 0.00 & 0.00 & 0.00 \\
& 2 & 0.00 & 1.00 & 1.00 & 1.00 & 1.00 & 1.00 \\
Gpi & 1 & 1.00 & 1.00 & 1.00 & 1.00 & 1.00 & 1.00 \\
He & & & 0.028 & - & 0.072 & 0.033 & 0.023 \\
A & & & 1.11 & 1.00 & 1.22 & 1.11 & 1.11 \\
P & & & 0.11 & 0 & 0.11 & 0.11 & 0.11 \\
\hline
\end{tabular}

$a$ : population samples 'La', 'Ln', 'S', 'C' and 'E'; see Table I.
TABLE III

F statistics at polymorphic loci among different populations of Triatoma rubrovaria from the State of Rio Grande do Sul, Brazil

\begin{tabular}{cccccc}
\hline & & \multicolumn{4}{c}{ T. rubrovaria populations } \\
\cline { 2 - 6 } & & 'Ln' & 'S' & 'C' & 'E' \\
\hline F de Nei & $P g m$ & - & 0.278 & - & - \\
& $M p i$ & -0.170 & - & -0.216 & -0.133 \\
$X^{2}$ & $P g m$ & - & 2.4011 & - & - \\
& $M p i$ & 0.8939 & - & 1.4421 & 0.3022 \\
\hline
\end{tabular}

$a$ : population samples 'La', 'Ln', 'S', 'C' and 'E'; see Table I.

A mean genetic distance of 1.11 was registered between the out-group and $T$. rubrovaria populations. The distances encountered between four $T$. rubrovaria populations ('Ln', 'C', 'La' and 'E') were very low (Ds $\leq 0.004$ ) when higher distances were observed between them and 'S' population (from 0.172 to 0.180 ) (Figs 3,4 ).

Four chromatic patterns according to the pronotum colors were found (Fig. 2): morphotype I with the anterior part black and the posterior extremity red; morphotype II with red spots in the laterals; morphotype III with three

TABLE IV

Chromatic frequency among five populations of Triatoma rubrovaria collected in different ecotopes or municipalities from the State of Rio Grande do Sul, Brazil

\begin{tabular}{lrcccc}
\hline & & \multicolumn{4}{c}{ Frequency of the morphotype (\%) } \\
\cline { 3 - 6 } Population $^{a}{ }^{a}$ & No. & I & II & III & IV \\
\hline 'Ln' & 49 & 8.1 & 55.1 & 26.5 & 10.2 \\
'La' & 35 & 11.4 & 48.5 & 28.6 & 11.4 \\
'S' & 45 & 0 & 0 & 0 & 100 \\
'C' & 46 & 4.3 & 10.9 & 2.1 & 82.6 \\
'E' & 10 & 20 & 30 & 30 & 20 \\
\hline
\end{tabular}

a: population samples ' $\mathrm{La}$ ', 'Ln', 'S', 'C' and 'E'; see Table I.

red spots in the posterior part; and morphotype IV with the pronotum entirely black without red spots. The frequency of the chromatic pattern according to the population is shown in Table IV.

\section{DISCUSSION}

The Santiago population ('S') showed heterozygosis only in Pgm locus (61.3\%) and homozygosis was detected in $38.7 \%$. The Pgm-2 allele was observed only in $3.2 \%$ of the total homozygotes for ' $S$ ' population when it was the only expressed by all other populations. The ' $S$ ' population was the most genetically variable, showing both the largest mean number of alleles per locus and the expected mean heterozygosity (Table II).

The phenogam based on Nei's distance suggests that 'Ln', 'La', 'C' and 'E' populations are very closely related and ' $\mathrm{S}$ ' is undoubtedly the most external population of the group. The genetic distance evidenced between ' $S$ ' 


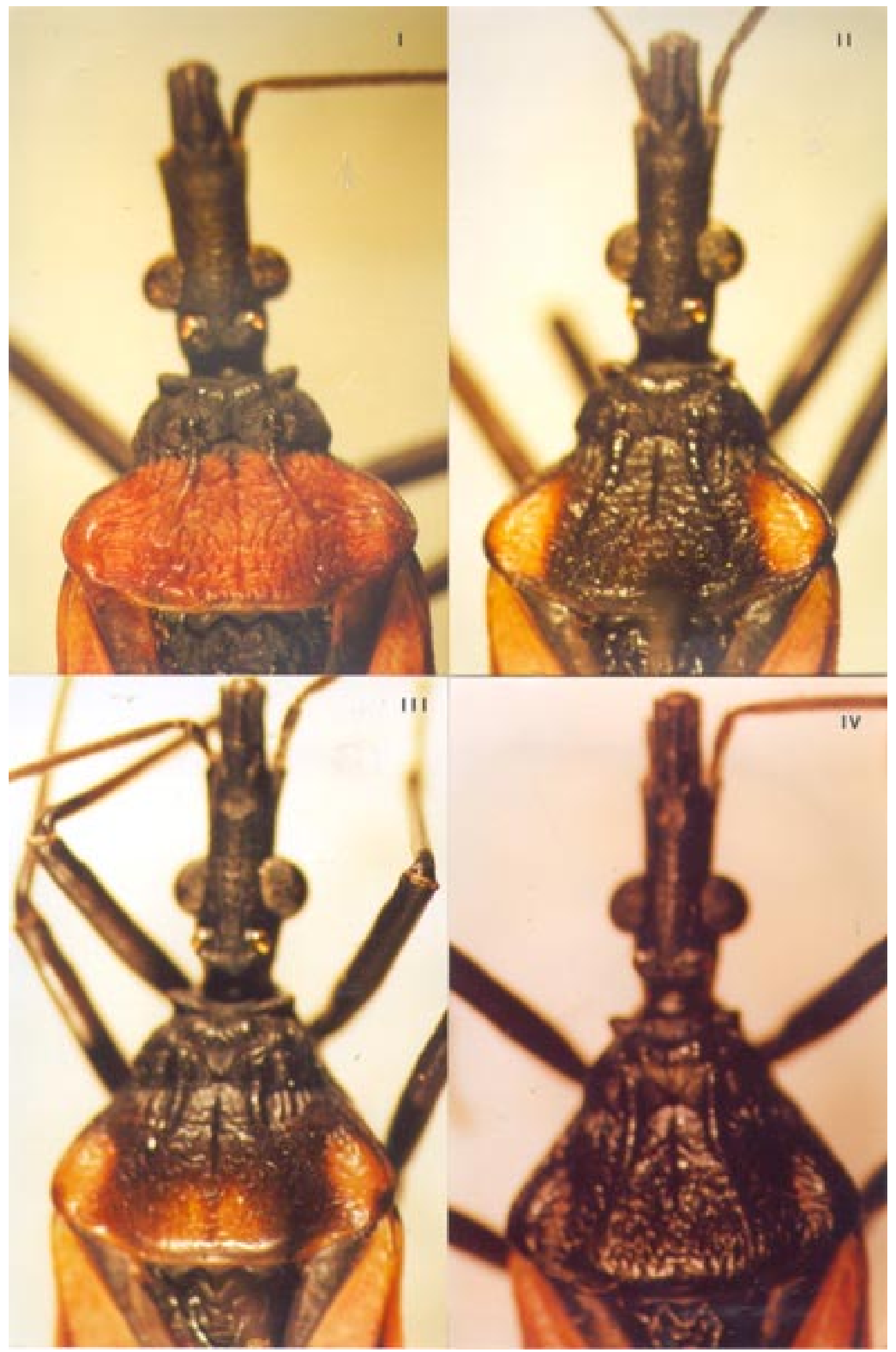

Fig. 2: chromatic variations of four morphotypes of Triatoma rubrovaria in the State of Rio Grande do Sul, Brazil. I: posterior extremity of pronoto red; II: presence of red spots in the laterals of pronoto; III: presence of three red spots in the posterior part of pronoto; and IV: pronoto without spots. 


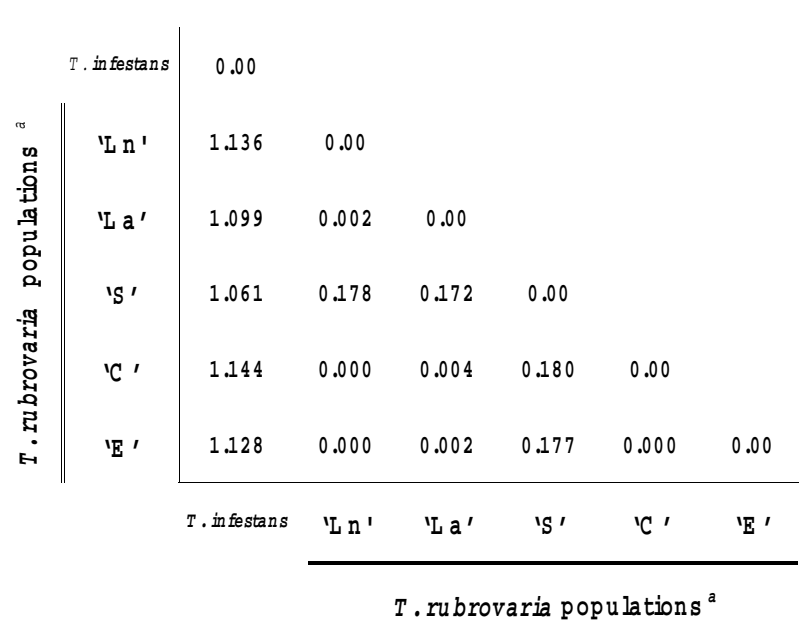

Fig. 3: Nei's genetic distance among different populations of Triatoma rubrovaria from the States of Rio Grande do Sul, Brazil. a: population samples 'La', 'Ln', 'S', 'C' and 'E'; see Table I.

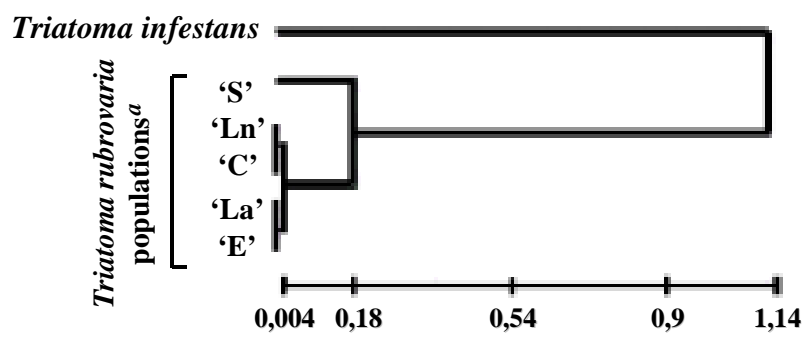

Fig. 4: dendrogram showing the genetic distances among populations of Triatoma rubrovaria. a: population samples 'La', 'Ln', 'S', 'C' and 'E'; see Table I.

and all other populations is two times lower than the interspecific distance observed between $T$. platensis and $T$. infestans by Garcia et al. (1995b), which had analyzed 14 loci. However, the distance obtained in our study between the ' $\mathrm{S}$ ' population and other $T$. rubrovaria populations was higher than the one registered by Pereira et al. (1996) between T. platensis and T. infestans $(0.09<\mathrm{Ds}<0.12)$ with 24 loci.

Isoenzymatic and chromatic analyses suggest that the ' $\mathrm{S}$ ' population is reproductively isolated. One diagnostic allele at the $I d h$ locus and two at the Pgm were found. ' $\mathrm{La}$ ' population collected in artificial ecotope displayed the lowest variability, with homozygosis in all studied loci.

The geographic distances between the municipalities do not vary according to the genetic distances. 'La', 'Ln', ' $C$ ' and 'E' populations are distant from 75 to $282 \mathrm{~km}$ and they presented a very low genetic distance (Ds $\leq 0.004$ ). 'Ln' and 'La' are the two closest populations in geographic term $(10 \mathrm{~km})$. They represent different samples of the same municipality (Santana do Livramento), were collected in distinct ecotopes, and the genetic distance found was 0.002 . However ' $C$ ' and ' $E$ ', which are $75 \mathrm{~km}$ distant, present a distance equal to 0 . Excluding ' $\mathrm{S}$ ' population, the highest geographic distance was found between ' $\mathrm{C}$ ' and ' $\mathrm{Ln}$ '/ 'La' $(282 \mathrm{~km})$ and the genetic distances are 0.000 and 0.004 , respectively. ' $S$ ' population is far from these localities from
220 to $322 \mathrm{~km}$ and shows a Ds $\geq 0.172$. This value is much higher than ever verified for T. infestans populations collected in different South-American countries (Dujardin et al. 1987, Garcia et al. 1995a). It might indicate the existence of reproductive barrier for the ' $\mathrm{S}$ ' population. For $T$. sordida populations collected in different sites in Bolivia, genetic distances were in accordance to the geographic ones (Noireau et al. 1999). On the basis of our allozyme data, genetic distances between $T$. rubrovaria populations were not found to be correlated with geographic distance.

'C' 'E' 'Ln' and 'La' populations would be populations showing a lack of reproductive barrier or would constitute the same recently dispersed population. Among them ' $\mathrm{C}$ ' and ' $\mathrm{La}$ ' populations were collected, respectively in peridomicile and artificial ecotope (stone walls $50 \mathrm{~m}$ far from domiciles). As suggested for T. infestans, the existence of geographically distant populations with low genetic distance might indicate recent dispersion of synanthropic subpopulations (Garcia et al. 1995a).

'Ln', ' $E$ ' and ' $S$ ' populations were always found in same sort of ecotope characterized by loose and overlapping rocks in dry environments on the prairies. The only detection of ' $S$ ' population in natural ecotope associated with its highest genetic variability may indicate that the Santiago municipality was the center of T. rubrovaria dispersion in RS. Thus, subpopulations adapted to anthropic ecotopes may have originated from ' $\mathrm{S}$ ' population. Although a detailed study would be necessary to confirm this hypothesis, we should emphasize that it is important to maintain the entomological vigilance to the synanthropic process of these triatomines.

Genetic distance verified for ' $S$ ' population may represent only a geographic variation in allopatric populations, indicating the existence of reproductive isolation due to geographic barriers. According to these analyses, T. rubrovaria is formed by at least two differentiated populations. This may result in different vectorial capacity, susceptibility for $T$. cruzi strains and insecticide resistance.

Isoenzymatic and chromatic results corroborate each other and favor the hypothesis of a distinct and isolated population. A higher number of enzymatic loci and the use of morphometric and other molecular tools as mitochondrial DNA would be necessary to confirm the reproductive isolation of ' $\mathrm{S}$ ' population.

\section{ACKNOWLEDGEMENT}

To Dr Maria Goreti Rosa Freitas for critical reading and for important suggestion. To Departamento de Medicina Tropical, Instituto Oswaldo Cruz by providing the Triatoma infestans specimens. To the technicians of National Health Foundation in Brazil for the support in the field captures. To the Centro Universitário de Barra Mansa for support.

\section{REFERENCES}

Almeida CE, Vinhaes MC, de Almeida JR, Silveira AC, Costa J 2000. Monitoring the domiciliary and peridomiciliary invasion process of Triatoma rubrovaria in the State of Rio Grande do Sul, Brazil. Mem Inst Oswaldo Cruz 95: 761768.

Correa RR 1968. Informe sobre a doença de Chagas no Brasil e 
em especial no estado de São Paulo. Rev Bras Malariol Doen Trop 20: 39-81.

Costa J, Freitas-Sibajev MG, Marchon-Silva V, Pires MQ, Pacheco RS 1997. Isoenzymes detect variation in populations of Triatoma brasiliensis (Hemiptera: Reduviidae: Triatominae). Mem Inst Oswaldo Cruz 92: 459-464.

Costa J, Almeida JR, Britto C, Duarte R, Marchon-Silva V, Pacheco RS 1998. Ecotopes, natural infection and trophic resources of Triatoma brasiliensis (Hemiptera, Reduviidae, Triatominae). Mem Inst Oswaldo Cruz 93: 7-13.

Di Primo P 1957. Atual distribuição geográfica dos triatomídeos e seus índices de infecção no Rio Grande do Sul. An Fac Med Porto Alegre 17: 17-37.

Dujardin JP, Tibayrenc M, Venegas E, Maldonado L, Desjeux $\mathrm{P}$, Ayala FJ 1987. Isoenzyme evidence of lack of speciation between wild and domestic Triatoma infestans (Heteroptera: Reduviidae). J Med Entomol 24: 40-45.

Garcia BA, Barata JMS, Blanco A 1995a. Enzyme polymorphism among Triatoma infestans (Hemiptera: Reduviidae) colonies. J Med Entomol 32: 126-133.

Garcia BA, Canale DM, Blanco A 1995b. Genetic structure of four species of Triatoma (Hemiptera: Reduviidae) from Argentina. J Med Entomol 32: 134-137.

IBGE-Instituto Brasileiro de Geografia e Estatística 1997. On line data: http: www.ibge.gov.br.

Lent H 1942. Estudos sobre os triatomíneos do estado do Rio Grande do Sul, com descrição de uma espécie nova. Rev Bras Biol 2: 219-231.

Lent H, Wygodzinsky P 1979. Revision of the Triatominae (Hemiptera, Reduviidae), and their significance as vectors as Chagas' disease. Bul Am Mus Nat Hist 163: 127-520.

Lucena DT 1959. Ecologia dos triatomíneos no Brasil. Rev Bras Malariol Doen Trop 11: 577-635.

Nei M 1987. Molecular Evolutionary Genetics, Columbia Uni- versity Press, New York, 512 pp.

Noireau F, Zegarra M, Ordonez J, Gutierrez T, Dujardin JP 1999. Genetic structure of Triatoma sordida (Hemiptera: Reduviidae) domestic populations from Bolivia: application on control interventions. Mem Inst Oswaldo Cruz 94: 347-351.

Pereira J, Dujardin JP, Salvatella R, Tibayrenc M 1996. Enzymatic variabity and phylogenetic relatedness among Triatoma infestans, T. platensis, T. delpontei and T. rubrovaria. Heredity 77: 47-54.

Rosa-Freitas MG, Broomfield G, Priestman A, Milligan PJM, Momen H, Molyneux DH 1992. Cuticular hydrocarbons, isoenzymes and behavior of three populations of Anopheles darlingi from Brazil. J Am Mosq Control Assoc 8: 357366.

Savatella R, Calegari L, Puime A, Basmadjian, Rosa R, Guerrero J, Martinez M, Mendaro G, Briano D, Montero C, Wisnivesky-Colli C 1994. Perfil alimentario de Triatoma rubrovaria (Blanchard, 1843) (Hemiptera, Triatominae) en ámbitos peridomiciliarios, de una localidad rural de Uruguay. Rev Inst Med Trop São Paulo 36: 311-320.

Salvatella R, Rosa R, Basmadjian Y, Puime A, Calegari L, Guerrero J, Martinez M, Mendaro G, Briano D, Montero C, Wisnivesky-Colli C 1995. Ecology of Triatoma rubrovaria (Hemiptera, Triatominae) in wild and peridomestic environments of Uruguay. Mem Inst Oswaldo Cruz. 90: 325-328.

Silva IG, Silva HHG 1993. Suscetibilidade de 11 espécies de triatomíneos (Hemiptera, Reduviidae) à cepa ' $\mathrm{Y}$ ' de Trypanosoma cruzi (Kinetoplastida, Trypanosomatidae). Rev Bras Entomol 37: 459-463.

Silveira AC, Rezende DF 1994. Epidemiologia e controle da transmissão vetorial da doença de Chagas no Brasil. Rev Soc Bras Med Trop 27 (Supl. III): 11- 22. 